\title{
WSPÓLNOTY LOKALNE \\ W GRECJI MIĘDZY \\ RELIGIĄ A ŻYCIEM
}

Ewa Nowicka

Uniwersytet Warszawski

\section{/// Wstęp}

Już parę lat temu Michael Herzfeld, który poświęcił wiele czasu badaniom terenowym w Grecji, napisał znamienne słowa: „Warto chyba zauważyć, że świat greckojęzyczny, będący w stanie wielkiego niepokoju i niepewności co do rzeczywistego charakteru swych relacji z »Europa«, znajduje się jednocześnie w położeniu równie niewygodnym, gdyż jest zmuszony do konfrontacji z równie kłopotliwym widmem, jakim jest »nowoczesność« (Herzfeld 2007: 127). Dziś w coraz większym stopniu tzw. opinia publiczna dochodzi do wniosku, że archaiczny świat społeczny Greków, zakonserwowany w niewiarygodnych strukturach sprzed stuleci, jest groźny dla całej Europy. Nie chcąc się wypowiadać na temat istotnego zagrożenia, jakie Grecy stwarzają Unii Europejskiej wraz ze wszystkimi członkami tej organizacji ponadpaństwowej, zamierzam jedynie wskazać na pewien aspekt greckiej kultury, która - nie stosując żadnych ocen przedstawia w swoich intensywnych przejawach lokalności wyjątkowo interesujący wzór dla antropologa. Pozornie jest to artykuł o współczesnej religijności greckiej; w istocie wdziera się on w tajniki i szczegóły ściśle lokalnej i terytorialnej (wioskowej lub wyspowej) więzi społecznej na obszarze Grecji, szczególnie ważnej dla zrozumienia społeczeństwa greckiego. Spróbuję to zrobić, sięgając do poziomu najprostszych zachowań społecznych, a także ograniczając analizę i wnioski do spojrzenia na zbiorowości lokalne. Natomiast niejako przypadkowy jest fakt, że niektóre z tych zachowań mają charakter religijny. Emil Durkheim znalazłby w tych analizach doskonała ilustrację swojej tezy, iż religia jest tam, gdzie społeczeństwo uprawia kult samego siebie (Durkheim 1990). Ucieszyłby się też 
z opisów uczestnictwa w obrzędach, które podaję niżej; miałby okazję podtrzymać swoją opinię, że „W bóstwie widzę jedynie społeczeństwo, przekształcone i przedstawione symbolicznie" (Durkheim 1963: 75).

Jak wskazują liczne badania religioznawców, ewolucja religijności zmierza w Europie albo ku totalnej sekularyzacji, albo ku całkowitej indywidualizacji, albo też ku przerodzeniu się w new age'owe zainteresowania o charakterze synkretycznym, albo wreszcie w magię, czary i wróżbiarstwo. Grecja dostarcza nieuwzględnianego w literaturze przykładu społeczeństwa, w którym rozwój ten przebiega jeszcze inaczej. Tam religijność przeradza się (lub też nigdy nie była czymś innym) w formę, którą określiłabym roboczo jako religijność społeczną lub wspólnotowa. Czy taka religijność to jeszcze religijność, czy praktyki stosowane przy okazji obrzędów kościelnych to w tym wypadku jeszcze praktyki, które zasługuja na miano religijnych, to pozostawiam do dyskusji w gronie religioznawców. Studium to nie ma charakteru historycznego, stąd diachroniczny aspekt zjawiska musi być pominięty, a to, co się da wyczytać z badań antropologicznych, dotyczy aktualnego - nomen omen - stanu rzeczy. Artykuł ten zawiera refleksję antropologa społecznego nad religijną obrzędowościa we współczesnej Grecji zarówno w środowisku wiejskim, jak i miejskim na terenie Macedonii Egejskiej. Materiał empiryczny pochodzi z kilkuletnich badań terenowych przeprowadzonych w latach 2005-2010 (Nowicka 2008a; Nowicka 2008b; Nowicka 2011) ${ }^{1}$. Będa mnie interesowały: zachowania uczestników obrzędów, mających w jakiejś części i w jakimś wymiarze charakter religijny, a także zróżnicowanie tych zachowań ze względu na różne cechy społeczne aktorów - ich wiek, płeć, miejsce w strukturze społecznej, historię rodziny. Będzie mnie również interesował stosunek do religii, uczestnictwo w religijnych obrzędach między innymi pewnej specyficznej kategorii Greków, migrantów powrotnych - tych, którzy powrócili (czasem w drugim pokoleniu) do rodzinnego kraju po długim okresie politycznej emigracji w Polsce i innych krajach tzw. demokracji

\footnotetext{
${ }^{1}$ W latach 2004-2007 realizowałam grant poświęcony greckim repatriantom z Polski, gdzie znaleźli się po klęsce komunistów w greckiej wojnie domowej trwającej w latach 1946-1949. (Był to grant Ministra Nauki i Informatyzacji nr 1H02E05127 pt.: „Powrót czy emigracja? Repatrianci greccy z Polski”). Drugie badanie terenowe realizowane w latach 2008-2010 dotyczyło małego bałkańskiego narodu Arumunów (Vlachów), którzy mieszkają w Albanii, Macedonii, Serbii, Bułgarii, a w największej liczbie w Grecji. (To badanie prowadziłam w ramach grantu Ministerstwa Nauki i Szkolnictwa Wyższego NN116284535, pt.: „Wołosi we współczesnej Europie - konstruowanie wspólnoty poprzez wyznaczanie granic etnicznych"). Badania te nie miały w centrum uwagi problematyki religijnej, ale musiały dotknąć problemów obrzędowości religijnej na terenie Grecji i związku religijności badanych z poczuciem lokalnej wspólnoty i innymi elementami kultury tego kraju.
} 
ludowej. Pojawią się także osoby, które spędziły wiele lat na emigracji zarobkowej w Niemczech. O wszystkich moich badanych piszę jako o Grekach, ale trzeba mieć świadomość, że znaczną część społeczeństwa greckiego, zwłaszcza na północy kraju - w Macedonii Egejskiej, Epirze i Tesalii - stanowią ludzie, których można byłoby bez trudu określić jako etniczne/narodowe mniejszości. A więc Grecy, o których piszę, to ściślej Arumuni (Vlasi, Wołosi), Pomacy, Sarakacanie, Macedończycy (Słowianie, czasem też określający siebie jako Bułgarzy). W wyniku wojny domowej 100 tysięcy etnicznie zróżnicowanych mieszkańców północnej Grecji zostało wyrwanych z rzeczywistości społecznej greckiej wsi i starannie wychowanych przez Komunistyczną Partię Grecji w ateizmie. Powracając do ojczyzny, wszyscy oni, bez względu na różnice etniczne, musieli się jakoś odnieść do specyficznej religijności (czy raczej religijnej obyczajowości) greckiej. W tym artykule nie będę uwzględniała ogólnopaństwowej czy ogólnonarodowej więzi o podłożu politycznym; odkładam do innej publikacji zastanowienie się nad budowaniem narodowej wspólnoty greckiej wśród zbiorowości etnicznie niegreckich. W tym miejscu podnoszę kwestię trwania i funkcjonowania więzi ściśle lokalnej - wioskowej, miasteczkowej, wyspiarskiej - oraz kwestię miejsca i roli, jaką pełnią obrzędy religijne w związku z tym typem wspólnoty.

Częścią rzeczywistości religijnej, na której koncentruję swoją uwagę, jest uczestnictwo w religijnych obrzędach, związanych $\mathrm{z}$ działalnościa Greckiego Kościoła Prawosławnego, a w tym zwłaszcza z obrzędowościa święta Zaśnięcia Matki Boskiej 15 sierpnia, oraz z takimi regularnymi rytuałami jak chrzty, śluby i niedzielne zwykłe msze. Przeanalizuję całość uroczystości Wniebowzięcia (Zaśnięcia) Matki Boskiej 15 sierpnia w kilku wsiach. Na koniec zagłębię się w problem adaptacji do greckiej rzeczywistości, w tym religijnej, tych mieszkańców Grecji (niekoniecznie greckiej przynależności etnicznej), którzy w tej religijności nie byli wychowani, ale wyrośli w greckich rodzinach na emigracji.

\section{/// Obchody święta Zaśnięcia Matki Boskiej 15 sierpnia}

Przedstawiam tu opis obchodów święta Zaśnięcia (w katolicyzmie: Wniebowzięcia) Matki Boskiej w dwóch górskich miejscowościach: jedna to mała wioska w rejonie Kilkis, na północ od Salonik, a druga to niegdyś duża wieś, dziś zaludniająca się tłumnie tylko podczas święta, Epir w rejonie Grevena. Obie wsie są i od niepamiętnych czasów były zaludnione przez ludność mniejszości arumuńskiej (vlaskiej, wołoskiej), mówiącej 
jeszcze do dziś (dotyczy to starszego pokolenia) językiem wołoskim, czyli wschodnioromańskim, podobnym $\mathrm{w}$ pewnym stopniu do rumuńskiego (Nowicka 2011).

\section{Loutra, sierpień 2006:}

Cały obrzęd rozpoczyna się w przeddzień właściwego święta, czyli 14 sierpnia. Na mszy tego dnia rano jest niewielu ludzi. Nie przyszedł jeszcze również stary ksiądz. Uczestnicy gromadzą się powoli, obrzęd się opóźnia, a publiczność - zmienia. Dopiero po wyjściu ze świątyni zaczyna narastać świąteczna atmosfera.

Już od godziny drugiej po południu daje się zauważyć ożywienie wśród mieszkańców, trwaja przygotowania do wieczornej uroczystości i przyjeżdża wielu gości z pobliskich wsi i dalszych okolic - przyjaciół i rodzin mieszkańców Loutry. Pojawiaja się też licznie osoby, które przedstawiano nam jako dalekich krewnych przybywających z różnych krajów Europy. Najliczniejsi są goście z Niemiec, gdzie ciagle pracuje wielu Greków pochodzących z górskich wsi. Zjeżdżają do rodzinnej wsi właśnie na to wielkie prawosławne święto.

Na głównej, zwykle pustej, piaszczystej drodze nie można zostawić nawet osła, ponieważ wszędzie stoja ekskluzywne auta (marek takich jak BMW, Mercedes, Audi, Volkswagen) głównie z niemieckimi tablicami rejestracyjnymi.

Mieszkańcy witają swoich gości już na ulicy, wszyscy wymieniają się pozdrowieniami i wrażeniami. Wyraźnie można odczuć świąteczny nastrój.

Około godziny 17 całe rodziny zaczynają zbierać się w okolicach tawerny, aby wspólnie poczekać do czasu rozpoczęcia obchodów Panaiji (Przenajświętszej, czyli Matki Boskiej). Starsi mężczyźni dobierają się w małe grupki i prowadzą rozmowy tylko w swoim gronie. Gdy podchodzi do nich obca kobieta (badaczka), nie okazuja jej niechęci, jednak nie są już całkowicie swobodni i tak rozmowni jak wcześniej.

Natomiast po południu tawerna tętni życiem. Z upływem czasu na zewnątrz sa rozstawiane białe ogrodowe stoliki i krzesła, a zespół muzyczny przygotowuje się do występu, rozkładając sprzęt. Teraz, czyli o zmierzchu, rozpoczyna się przedstawienie, które, jak nas informowano, jest wiernym odtworzeniem tradycyjnych zwyczajów według ustnych i pisemnych przekazów. Instrumenty muzyczne maja jednak charakter zdecydowanie nowoczesny - syntezatory, a nie tradycyjne buzuki.

Po jakimś czasie ludzie siadaja przy stołach i rozmowy są kontynuowane przy posiłku. Tego wieczoru tawerna serwuje tradycyjne potrawy kuchni 
greckiej: suflak barani, sałatkę grecką (tu nazywaną po prostu wiejska), tzatziki, sery kozie i frytki, wszędzie już uznawane za tradycyjne. Pije się głównie napoje bezalkoholowe, gdzieniegdzie na stoliku stoi butelka wina, nie wznosi się toastów. Goście nie są ubrani w stroje galowe ani oficjalne, widać tylko jednego mężczyznę w garniturze, reszta uczestników święta ubrana jest w stroje codzienne, przeważnie dżinsy, T-shirty, czasem koszule. Atmosfera odznacza się wesołą swojskościa - wszyscy dają do zrozumienia, że się dobrze znaja, że ich spotkanie jest źródłem radości.

Między mieszkańcami i gośćmi przechadzaja się ubrani w tradycyjne wołoskie stroje członkowie zespołu tańca ludowego. Mężczyźni noszą długie białe koszule (mniej więcej do pół uda), czarne spodnie, wierzchnie odzienia na kształt marynarki z rozciętymi rękawami w kolorze czarnym, czerwone czapki z pomponami oraz czarne buty, w rękach trzymają ozdobne laski pasterzy wołoskich, przypominające znane w Polsce góralskie ciupagi. Kobiety z zespołu mają czerwone chustki, białe sukienki, na które włożyły czarne haftowane kubraczki (podobne do tradycyjnej kamizelki podszytej futrem) oraz podobnie jak mężczyźni, czarne buty.

Młodzież występująca w przedstawieniu ubrana jest na galowo: dziewczynki w czarne spódniczki, chłopcy w czarne spodnie, białe koszule, na szyjach zawiązane ciemnoczerwone chusty, a w rękach białe chusteczki. Mniej więcej około godziny 21 zespół rozpoczyna przygotowania do przedstawienia. Konferansjer z zespołu opowiada wszystkim zebranym o tradycyjnych obchodach święta Wniebowzięcia Najświętszej Marii Panny i o występie przygotowanym przez zespól. Co roku wybierany jest inny obyczaj do przedstawienia. Rok wcześniej był to ślub, w tym roku miały być uroczyste obchody związane ze świętami pasterskimi. W skład zespołu wchodza mężczyźni i kobiety (około pięciu par) oraz młodzież. Z wyjątkiem ludzi młodych (którzy trzymają w rękach chustki) wszyscy niosą różne przedmioty, takie jak: chleb, kadzidło, oliwę, świeczki, dzbanek na wino bądź oliwę, dywaniki, stoliczek, plastikowa owca - przedmioty, które potem będą użyte podczas obrzędu. W momencie rozpoczęcia przedstawienia członkowie zespołu rozkładają wszystkie przedmioty tak, jakby przygotowywali się do uczty: stawiają w środku kręgu stolik, dookoła niego układaja dywaniki i wszyscy zasiadaja do stołu (rozmawiaja, pija alkohol, żywo gestykulują, śmieją się) - na scenie odbywa się praktycznie to samo co na widowni, jedno stanowi wzór drugiego, a wszystko sprowadza się do ceremonialnego bycia razem i czerpania z tego radości, poczucia bezpieczeństwa we wspólnocie. W tym samym czasie młodzież formuje wężyk i zaczyna tańczyć. Po pewnym czasie kobiety wstaja, przy stoliku 
zostają sami mężczyźni, a kobiety chodzą po obwodzie koła i machają białymi chustkami nad głowami. Najstarsi członkowie zespołu sa przywódcami przedstawienia-rytuału, rodzajem starszyzny. Po pewnym czasie jeden z przywódców tańca wstaje, dzieli przyniesiony chleb i zaczyna częstować nim publiczność, wznosi również kilka toastów. Do mężczyzn w kółku dołącza najstarsza kobieta, podaje im napoje i jedzenie.

Po skończonej uczcie wszyscy wstają i zaczynaja tańczyć, w najbardziej zewnętrznym kole tańczy i klaszcze młodzież. Dziewczynki trzymaja ręce nisko, a chłopcy wysoko, pośrodku pozostali tancerze (spleceni ramionami), a w samym środku najstarsza para (mężczyzna co jakiś czas macha laska). Po pewnym czasie członkowie zespołu zaczynaja zapraszać do tańca ludzi siedzących przy najbliższych stołach. Takim płynnym przejściem kończy się występ, a rozpoczyna wspólna zabawa. Trwa do godziny drugiej w nocy. Ludzie tańczą powszechny w Grecji taniec syrtó (wszyscy oplatają się ramionami i wyrzucają nogi w prawo i w lewo, czasami przytupuja) oraz męski taniec zejbekiko. Tańczy się także tradycyjne wołoskie tańce, już niewykonywane na co dzień, znane zwykle tylko najstarszym ${ }^{2}$.

Podczas zabawy tańczy się tylko zbiorowo, rzadko w parach, prawie nigdy pojedynczo. Pojawia się dosłowna bliskość fizyczna - splatają się dłonie, czasem ramiona, a ludzie wykonują te same ruchy, posuwając się dobrze znanymi krokami wokół placu. Powstaje wrażenie, że daje to tańczącym poczucie jedności i solidarności, a z tańca tworzy się element budujący trwałe więzi społeczne. Nawet osoby starsze z Loutry, niezdolne do zabawy, przychodzą na obchody świąt, takich jak święto 15 sierpnia, tylko po to, by jak same określają, „pobyć ze swoją wsią”. Nie chcą się izolować $\mathrm{w}$ wygodnych fotelach przy stolikach na tarasie kawiarni, pragną być razem ze wszystkimi, co wyrażają expressis verbis. Wspólna zabawa, przebywanie razem, wykonywanie wspólnie wielu czynności rytualnych, które wprawdzie wiążą się ze świętem religijnym, ale daleko sięgają w życie świeckie, pełni więc jawne funkcje integracyjne - uczestnicy zresztą zupełnie otwarcie podkreślają ten aspekt zbiorowego zachowania; sa

\footnotetext{
${ }^{2}$ Opisywano nam je jako:

- Taniec Patruny, inaczej Al Patruna (nazwa pochodzi od kobiecego imienia Patruna),

- Muszesku (tak zwany taniec starych),

- Turnatu,

- Pusestrima (tańczą go dwie osoby stojące naprzeciwko siebie),

- Taniec Jani, inaczej Al Jana (jego nazwa również pochodzi od kobiecego imienia Jana),

- Kalamatianos (tańczony w całej Grecji),

- Taniec Aleksandra Wielkiego,
}

Lemi-lemi Itu (jeden z niewielu utworów muzycznych, do których się nie tańczy, jest to piosenka z sąsiadującej z Loutrą wioski o nawie Archangelos). 
świadomi sensu wspólnotowego zabawy, w której wszyscy są zarazem widzami i uczestnikami. W rozmowach z badaczką wielokrotnie dają wyraz zadowoleniu, że są razem, że ta wspólna zabawa jest czymś, na co długo czekali. Opowiadają o tych, którzy przybyli z daleka, o tym, że tu się zawsze spotykają. Wspominaja też o tych, którzy przybyć nie mogli i zawsze temu towarzyszą żal i przekonanie, że w następnym roku to się uda. Komunikują sobie wzajemnie to poczucie, które Michael Herzfeld nazwał ,intymnością kulturową" (Herzfeld 2007) ${ }^{3}$.

Około godziny drugiej w nocy zabawa się kończy - wszyscy szybko rozchodzą się do domów. Jednak długo, aż do następnego roku, będą wspominali wspólnie odbytą uroczystość.

\section{Samarina, sierpień 2007:}

Samarina jest wielką wsią położoną wysoko w górach (1600-1800 m n.p.m.) pod wielkim szczytem Zmolikas. W tradycji greckiej, a zwłaszcza wołoskiej (arumuńskiej) miejscowość ta nabrała znaczenia symbolicznego: śpiewa się o niej piosenki, opowiada historie z mitycznej przeszłości. Obrzędy święta Wniebowzięcia Matki Boskiej są odprawiane bardzo uroczyście, a ludzie, którzy się tam zbierają, to nie tylko mieszkańcy, dawni mieszkańcy i ich rodziny przybyłe $z$ dala. Przybywają także goście z innych okolic Grecji, zwykle Wołosi. Pojawiają się też mieszkańcy tej wsi lub innych wsi arumuńskich (wołoskich) mieszkający dziś za granica. Wszyscy Wołosi w Grecji, ale także Grecy mieszkający na północy kraju wspominaja o uroczystościach w Samarinie, zachęcają nas do przyjazdu 15 sierpnia, podkreślając, że warto te uroczystości zobaczyć.

Obchody rozpoczynają się na kilka dni przed właściwym świętem. Zbierają się rodziny z całej Grecji i nawet ze świata, żeby razem świętować Panaiji (Zaśnięcie Matki Boskiej). Wśród uczestników później spotykamy osoby, które specjalnie przyjechały z Rumunii, a których rodziny wyemigrowały w latach 20. z innej wsi arumuńskiej (wołoskiej) do Dobrudży (Nowicka 2011: 124-138). Słowem, zbierają się ludzie połączeni więzią rodzinna, ale też regionalną i etniczna, a poczucie wspólnoty wiąże ich już w momencie przybycia. Przyjeżdżaja, żeby być razem z tymi, którzy podobnie czują i którzy należą do zbiorowości. W wypadku Samariny do uprzednio opisanego poczucia wspólnoty lokalnej - wioskowej

\footnotetext{
${ }^{3}$ Tytuł książki „Cultural Intimacy” polski tłumacz oddał jako „Zażyłość kulturowa”, co jest pewną opcją wykładni sensu zwrotu. Chętnie pozostałabym przy łacińskim pierwowzorze ,intymność”, gdyż termin ten odnosi nas do takich form bliskości między ludźmi, która wynika z podobieństwa socjalizacji i świadomości tego podobieństwa.
} 
- dochodzi element wspólnoty etnicznej Wołochów (Arumunów), który pojawia się w związku z tym, że wieś Samarina nabrała sensu tożsamościowego dla Arumunów na całych Bałkanach oraz żyjących w diasporze.

Kilka orkiestr gra na zmianę na głównym placyku wsi, gdzie przy stolikach siedzą mieszkańcy, zmieniając się w trzech głównych tawernach. Muzyka instrumentalna ma charakter etniczny, „regionalny”, jak wolą mówić o niej Grecy. Należy tu podkreślić, że oficjalnie mniejszość wołoska, jak wszystkie mniejszości etniczne czy narodowe, nie jest uznana w Grecji, mimo że kraj ten należy do Unii Europejskiej od początku jej istnienia ${ }^{4}$. Kultura wołoska była dokumentowana w 1914 roku przez dwóch angielskich badaczy: Alana Wace'a i Maurice’a Thompsona. Ich książka w tłumaczeniu greckim z ilustracjami przedstawiającymi Samarinę niemal sprzed stu lat sprzedawana była w dniach poprzedzających święto w 2007 roku przy głównym placyku przez aktywistów etnicznego ruchu wołoskiego. W dniu 14 sierpnia po południu odbyło się uroczyste nabożeństwo w cerkwi. Wszyscy niezwykle starannie, odświętnie ubrani. Stroje mają charakter miejski, ogólnoeuropejski, nie rzucają się w oczy regionalne stroje wołoskie. Po nabożeństwie wszyscy, wychodząc, witają się, ściskaja, gawędza, a następnie część osób udaje się do miejscowej biblioteki, ciagle na terenie wokół cerkwi, aby obejrzeć wystawę strojów regionalnych z terenów Epiru. Zainicjował ja miejscowy działacz i intelektualista, zwany Johnem, który siedem lat spędził w Stanach Zjednoczonych, a teraz odwiedza w Samarinie swoją babkę.

Z każdym dniem, zbliżającym uczestników do święta 15 sierpnia, atmosfera świąteczna narasta i sięga szczytu wieczorem 14 sierpnia po nabożeństwie i wizytach w muzeum etnograficznym, kiedy to wszystkie orkiestry graja naraz, a ludzie biesiaduja we wszystkich tawernach i tańczą zbiorowo i indywidualnie. Wielki bęben, który słychać na odległość kilku kilometrów od wioski, daje znać o odbywającej się zabawie do późnych godzin nocnych.

Teraz następuje kulminacja całego obrzędu - zaczyna się corlu mare - wspólny rytualny taniec ze wspólnym śpiewem o bardzo archaicznej melodii i sposobie wykonania. Uczestnicy, na razie tylko ci, którzy są ubrani w uroczyste stroje etniczne, ustawiaja się w krag, jest ich co najmniej kilkudziesięciu. Powoli i dostojnie, z namaszczeniem, pewnym napięciem i wielką uwagą zaczynaja się posuwać, trzymając za ręce. Jedna grupa, która robi wrażenie prowadzącej taniec - dostojny korowód - śpiewa

${ }^{4}$ Jeden $\mathrm{z}$ moich rozmówców w wołoskiej wiosce w górach Pajkos tak się ironicznie wyraził na ten temat: „U nas wszyscy są Grekami, także psy i koty, które tu biegaja”. 
fragment melodii, z innego punktu kręgu odpowiada jej inna grupa. Melodia ma brzmienie surowe, archaiczne. Następnie w szerszych koncentrycznych kręgach przyłączają się do poprzedników kolejno wszyscy, tworząc jeszcze dwa dalsze kręgi. Taniec stopniowo staje się szybszy, bardziej energiczny i zarazem bardziej chaotyczny. Do środka wchodzi grupa osób fotografujących. Nie jest to bynajmniej grupa turystów. Obcych tu właściwie nie ma poza nami ${ }^{5}$, które jesteśmy brane za córkę i wnuczkę Thompsona, pierwszego badacza Samariny z Wielkiej Brytanii i współautora książki właśnie sprzedawanej w tłumaczeniu greckim. O to, czy istotnie jesteśmy rodziną brytyjskiego badacza, nas ludzie nie pytają, co świadczy o tym, że nie spodziewaja się turystów. Po jakimś czasie do kręgu wchodzi orkiestra i zaczyna się poważny, rytmiczny, powolny taniec z muzyka, w której wybija się wielki bęben. Teraz atmosfera osiaga punkt kulminacyjnego napięcia, a wspólnota nabiera silnego, pierwotnego wyrazu. Stopniowo napięcie opada, a po zakończeniu tańca jeszcze długo ludzie rozmawiają w grupkach, po dłuższym czasie przenoszą się razem z orkiestrą, która teraz przejmuje przewodnictwo, na główny placyk. Tam część ludzi zajmuje miejsca przy stolikach, a inni rozchodzą się do domów. Wszędzie się je pieczonego barana. Poprzedniego dnia zarżnięte barany wisiały przed domami i restauracjami, stwarzając trochę makabryczna atmosferę. Teraz zostają zbiorowo zjedzone. Choć część uczestników rozchodzi się do domu, to jednak wszyscy będą identycznie ucztowali. Wspólne konsumowanie barana towarzyszy wszystkim ważniejszym świętom i religijnym, i niereligijnym w wioskach Grecji. Wieczorem samochody zaczynają opuszczać wieś, ale część gości zostanie dłużej.

Corlu mare, archaiczny wspólny taniec, inicjowany nie bez przyczyny przez osoby w tradycyjnych strojach, jest centrum całego obrzędu nie tylko w oczach odbiorcy zewnętrznego. To na ten taniec zapraszali nas wszyscy rozmówcy w ciagu poprzedzających dni, to o nim przypominali nam, zaznaczając, że musimy zapamiętać miejsce i godzinę, podkreślali wagę tego wydarzenia. Nosi nazwę corlu mare (lub corlu mari - w zależności od lokalnej wymowy w języku arumuńskim, wołoskim). Corlu mare oznacza „Wielki Taniec”, a dokładnie wielki zbiorowy taniec w kręgu. Jest to obrzęd odprawiany w różnych sytuacjach, przy różnych okazjach i w różnych krajach zamieszkania społeczności arumuńskiej nieco odmiennie. ( Por. Nowicka 2009b). Corlu mare tańczy się przy różnych okazjach także współcześnie; zawsze ma związek ze wspólnotą lokalną, ale także z etniczną

\footnotetext{
${ }^{5}$ W sezonie letnim 2007 r. moje badania na terenie Bałkanów prowadziłam razem z Martą Olejnik, doktorantką w Zakładzie Antropologii Społecznej Instytutu Socjologii Uniwersytetu Warszawskiego.
} 
wspólnotą arumuńska, choć aspekt etniczny jest ukazywany z dużo większą wyrazistością w Rumunii, Bułgarii czy Macedonii niż na terenie Grecji ${ }^{6}$.

Wspólnota jest w nim zaznaczana w sposób niezwykle intensywny. Ma też wymiar historyczny, czasowy, gdyż prowadzącymi taniec są osoby starsze, co najmniej w średnim wieku, w nienagannie tradycyjnych strojach, podkreślających wspólnotowe korzenie. Uderza obserwatora intensywność więzi, która się manifestuje w trakcie tańca, stan napięcia wspólnoty - skrajne przeciwstawienie stanu anomii. Znamienne też, że taniec w Samarinie odbywa się na zamkniętym placyku przed cerkwią, z której wszyscy wychodzą po nabożeństwie. Taniec wspólnotowy jako aktywność rytualna całej zbiorowości styka się bezpośrednio z tym, co przed chwila zdarzyło się w świątyni. W tych miejscowościach, w których koło kościoła nie ma wystarczająco dużo miejsca dla obrzędów, corlu mare odbywa się zawsze po obrzędach o charakterze religijnym, zawsze jest ich kontynuacja. Znowu to, co się zdarzyło w świątyni, stanowi jedność z tym, co się zdarza wśród uczestników przed świątynią. Znowu wspólnota uczestników jest celem obu części wydarzenia.

\section{/// Wspólnota lokalna i budowanie więzi etnicznej}

Jednocześnie w obrzędzie w Samarinie zauważymy nowy wątek wspólnotowy, który tym razem obok ewidentnego wątku wspólnoty lokalnej odnosi się do ponadlokalnej, ponadregionalnej, ponadpaństwowej wspólnoty etnicznej Arumunów (Wołochów, Vlachów). Obrzędy wokół święta 15 sierpnia odbywały się tu od niepamiętnych czasów i miały charakter lokalny, taki jak opisywany wcześniej we wsi Loutra w górach Pajkos. Tu, w Samarinie, pojawiają się osoby, które traktuja ja jako wyjątkowo ważne miejsce dla swojej grupy etnicznej, choć mieszkają na stałe w Dobrudży (Rumunia), a ich przodkowie wywodzą się ze wsi odległych od Samariny o 300 kilometrów. Teraz w Samarinie widzimy, jak „pokazanie się światu”, „autoprezentacja” i walka o uznanie przez świat, a zwłaszcza Europę, swojego istnienia wymaga publicznego (nie tylko podtrzymywanego wewnątrz grupy) ukazania swojej specyfiki kulturowej. Tańce, prezentowane teraz już nie tylko samym sobie i wykonywane nie tylko we własnym gronie, są dziś pokazywane publicznie bez wątpienia dla przedstawienia swojego

\footnotetext{
${ }^{6} \mathrm{Z}$ pewną konsternacją liderzy arumuńscy przyjęli na wielkich obrzędach w Moskopolu w 2010 roku w dniu 15 sierpnia fakt, że organizatorzy nie zadbali o to, żeby po przemówieniach i koncercie odbył się taniec wspólnotowy - corlu mare. Fakt, że po tak ważnej ponadpaństwowej uroczystości, która zebrała Arumunów ze wszystkich krajów stałego zamieszkania oraz z emigracji, taniec się nie odbył, odebrałam jako symptom głębokich przemian w obrębie arumuńskiej wspólnoty etnicznej.
} 
zaplecza, bagażu i potencjału kulturowego, swojej niepowtarzalności - swojego „kustomu” (Keesing 1996; Sahlins 2006). Na przykładzie święta Wniebowzięcia Matki Boskiej i sposobu jego obchodzenia można dotrzeć do sensu ważnych procesów w obrębie społeczności Arumunów. Trzeba zauważyć, że święto Wniebowzięcia Matki Boskiej jest zarazem po prostu prawosławne, obchodzą je również wszyscy prawosławni, którzy nie sa Arumunami. W Grecji sa to przede wszystkim Grecy, ale także Macedończycy (czasem określający siebie jako Bułgarzy); w innych krajach prawosławna część Albańczyków, Serbowie, Macedończycy, Bułgarzy. W przebiegu święta wyraża się przede wszystkim związek określonej grupy ludzi z określonym miejscem, zwykle zarazem miejscem zamieszkania lub też przynajmniej pochówku ich przodków. Bez wątpienia zaznacza się w sposobach ich obchodzenia więź lokalna, wioskowa. W innych wsiach, w których w latach 2008 i 2009 obserwowałam obchody święta 15 sierpnia, aspekt wioskowej więzi dawał o sobie znać bardzo wyraźnie. Przejawiał się w tym, że młodzi intelektualiści organizowali poszczególne elementy kilkudniowych obchodów święta, przygotowując, tak jak to miało miejsce w 2009 roku w Kleisourze, inscenizację scenek rodzajowych osnutych na treści tradycyjnych wioskowych opowieści o „dobrym i złym pasterzu”. To oni w poczuciu więzi z rodzinną wsią organizowali wioskowe muzeum, dbali o zgodny z tradycja przebieg kolejnych etapów święta, w którym zbiorowe odtańczenie corlu mare stanowiło kulminację obchodów. Zawsze ten taniec, w którym porządek tańczących oddaje porządek tradycyjnej społecznej struktury wioski z męską starszyzną na czele, nosił znamiona wydarzenia zbiorowego zachowania niosącego z sobą maksymalne nasilenie więzi wśród uczestników obrzędu, aktualnych mieszkańców wsi i tych wszystkich, w których tożsamości związek z tą wsią i pochodzenie z niej zajmuje główne miejsce. We wszystkich omawianych i przywoływanych mniej szczegółowo przypadkach społecznego wydarzenia, jakim jest święto Zaśnięcia Matki Boskiej, najważniejszy wkład organizacyjny miały najczęściej młodzieżowe stowarzyszenia, skupiające osoby, które z danej wsi pochodzą, choć w niej najczęściej nie mieszkaja. To oni są dumni z przynależności do swoich społeczności wiejskich, mają za nie poczucie odpowiedzialności, działają na ich rzecz. Podczas kolejnych etapów badania terenowego spotykałam się z takimi osobami, które czasem reprezentowały inteligencję uniwersytecka $\mathrm{z}$ odległego miasta, ale pochodziły $\mathrm{z}$ konkretnej wioski. 


\section{/// Więź regionalna/etniczna}

Analiza tego ostatniego obrzędu wyprowadza badacza poza więź ściśle lokalną, choć jej bynajmniej nie zaprzecza. Oprócz ściśle lokalnego, wioskowego aspektu, który jest powszechnie zrozumiały i akceptowany, dla części elity intelektualnej, również częściowo przynajmniej wioskowej, pojawia się nowy aspekt - jest nim aspekt solidarności etnicznej, w Grecji etykietowanej jako regionalna, manifestującej się podczas opisywanego święta. We wsiach zamieszkanych przez Wołochów/Arumunów obchodzone jest wyjątkowo uroczyście. Obserwować możemy na przykładzie tych świąt proces emblematyzacji grupy etnicznej/regionalnej, nadające znaczenie określonym zachowaniom i przedmiotom (Lubaś 2008; Nowicka 2009a), który tworzy nową formę etniczności, a w tym wypadku raczej regionalizmu. W życiu codziennym, ale także w trakcie obrzędów, które miejscami nabieraja sensu obrzędów etnicznych, większość osób jest ubrana po europejsku, mało kto jest ubrany etnicznie, regionalnie. Jednak to właśnie ci ostatni pokazują to, co jest nasze, co jest znakiem własnej grupy, nadają sens wspólnemu tańcowi corlu mare. Następuje zatem zagospodarowanie obrzędu pierwotnie o sensie czysto lokalnym do celów ideologicznych grupy etnicznej, która - bardziej lub mniej otwarcie (w Grecji w sposób bardzo delikatny i zakamuflowany) - walczy o uznanie jej jako zbiorowości mającej status osobnej grupy etnicznej/narodowej. W tej autoprezentacji wydaje się zawarte żądanie: „Mamy prawo do samodzielnego bytu, mamy prawo do europejskich funduszy, bo mamy coś, czego inni nie mają, co tylko my możemy zachować i to coś jest warte zachowania". Jednakże zauważmy, że tylko w społeczeństwie, w którym doceniana jest wartość rozmaitości i odmienności, a zwłaszcza odmienności kulturowej, działanie takie może uzyskać jakiś rezultat, może być skuteczne. Normy europejskie zapewniają ochronę mniejszościom kulturowym, kulturom marginalnym oraz przeciwdziałaja procesom całkowitej asymilacji, pomagaja grupom, których kultura jest w stanie zagrożenia. Można nawet powiedzieć, że europejskie instytucje są specjalnie tworzone dla zapewnienia naszym społeczeństwom kulturowego pluralizmu i wielokulturowości. Jednakże właśnie Grecja jest jednym z dwóch krajów Unii Europejskiej - towarzyszy jej tylko Francja - które nie uznają istnienia na swoim terytorium żadnych mniejszości etnicznych i narodowych.

Chrześcijaństwo przez długie stulecia pełniło na terenie imperium otomańskiego istotną funkcję polityczną - ludność dzieliła się na milety, czyli zbiorowości religijne, mające w państwie odrębny status. Władcami o najwyższej pozycji byli nieodmiennie muzułmanie, bez względu na ich 
etniczną przynależność. Chrześcijanie, również bez względu na ich etniczna afiliację, byli w pozycji poddanych. Przynależność religijna tworzyła wspólnotę interesów i więź społeczna.

Ważnym elementem sprzyjającym zarówno w przeszłości, jak i - w coraz większym stopniu - w czasach współczesnych, który sprzyjał akceptacji tożsamości greckiej lub - częściej - mieszanej, była renoma, prestiż greckiej starożytności. Wszyscy nieetniczni Grecy, tzn. obywatele Grecji niebędący greckiej narodowości/etnicznej przynależności akcentują swoja dumę z greckiej historii, kultury, wielkiego spadku, który grecka kultura ofiarowała Europie. Wszyscy jednomyślnie podkreślają, że to język grecki jest źródłem całego abstrakcyjnego słownictwa naukowego, że to filozofia grecka stworzyła myślenie europejskie, choć zarazem niektórzy z arumuńskiej mniejszości (w sensie polskim) w Grecji podkreślają to, że wszystkie wielkie historyczne budynki w Grecji zbudowali nie tyle etniczni Grecy, ile Vlasi (Arumuni), czyli przedstawiciele ich grupy. To Akropol, politechnika w Patras i wiele instytucji powstało dzięki darowiznom i patronatowi arumuńskich (vlaskich) biznesmenów, którzy zawsze byli przedsiębiorczy, energiczni i lojalni wobec kraju, który był ich krajem. Wśród Arumunów, zwłaszcza starszego pokolenia, obecne jest też przekonanie, że większość wielkich ludzi z historii greckiej starożytności to byli Arumuni. Dotyczy to najbardziej politycznie spornej i nośnej postaci historycznej, którą jest Aleksander Macedoński.

\section{/// Religijność w życiu zbiorowości wioskowej a kategorie durk- heimowskie}

Obraz religijności w lokalnych społecznościach w Grecji dokładnie i dobitnie obrazuje socjocentryczną koncepcję religii Emila Durkheima, w której idea zbiorowości w umysłach jednostek stanowi podstawę i wymóg si ne qua non życia społecznego (Durkheim 1990: 333). Według Durkheima przez obrzędy religijne dokonuje się inicjacja jednostki do życia zbiorowego. Jerzy Szacki komentuje ten aspekt myśli Durkheima następująco: „Postulatem durkheimowskiego praktycznego rozumu nie był bóg jakiejś tradycyjnej religii, nawet nie Bóg Kanta, lecz społeczeństwo swoiście odrębne od indywiduów. To społeczeństwo właśnie, wpływając "z zewnątrz« na jednostkę, czyni z niej istotę rozumną i moralną" (Szacki 2002: 378). Obrzęd religijny, z którym miałam do czynienia w różnych okolicznościach w północnej Grecji, daleko odbiega od tego, co zaobserwować można w kościołach rzymskokatolickich, protestanckich czy nawet $\mathrm{w}$ cerkwiach prawosławnych $\mathrm{w}$ innych krajach europejskich. Jest przede 
wszystkim zjawiskiem społecznym, a akt duchowy odbywa się jakby w innej sferze, „ponad”, „obok” tej społecznej rzeczywistości, uzasadniając, sankcjonując, nadając zarazem wagę i znaczenie temu społecznemu porządkowi.

Dla obyczajowości cerkiewnej w Grecji charakterystyczny jest sposób uczestniczenia w praktykach religijnych, który można określić jako „wspólnotowy”, a nie indywidualistyczny. Nie jest to religijność mistyczna, kontemplacyjna ${ }^{7}$. Uderza polskiego katolika to, że: zbiorowość, która coś razem przeżywa, nie wyraża w gestach rytualnych znaczeń, które się w tej wspólnocie tworzą w związku z aktem religijnym. To sama wspólnota wydaje się mieć jako taka aspekt sakralny. Nie słowa wypowiadane podczas religijnego obrzędu, nie przedmioty, gesty, melodie, ale zbiorowość jest celem. Religijność obserwowaną w greckich społecznościach lokalnych można opisać jako świeckość zabarwioną religijnie, religijnie usankcjonowaną. Przedstawić ją można jako wspólnotę w religijności zanurzoną czy raczej ugruntowaną w sacrum - w rytuale. Wydaje się, że Durkheimowska koncepcja religii jako społecznie ugruntowanej, realizującej się i mającej swój cel w życiu społecznym idealnie opisuje przypadek lokalnych wiejskich społeczności na terenie Grecji - wioskowych, małomiasteczkowych, zawsze opartych na więziach wielkorodzinnych i sąsiedzkich. Zachowania, które zaskakują badacza przywykłego do obrzędowości katolickiej, protestanckiej czy prawosławnej w Polsce, takie jak wchodzenie do cerkwi, wychodzenie $\mathrm{z}$ niej $\mathrm{w}$ trakcie wielogodzinnego nabożeństwa, zachowania czysto towarzyskie na terenie świątyni, nie wynikają, jak się zdaje, z ignorowania tego, co się dzieje wewnątrz cerkwi. Wydaje się, że w greckiej wiosce czy miasteczku jest się w cerkwi zarówno wtedy, gdy się stoi lub siedzi wewnątrz, jak i wtedy, gdy się przebywa na zewnątrz, zapalając świeczki, rozmawiając ze znajomymi, komentując wydarzenia lokalne i rodzinne. Bycie wewnątrz świątyni i na zewnątrz nie pozostaje w sprzeczności - tworzy pewien rodzaj całościowego aktu, który wyraża się przede wszystkim w wymiarze społecznym, swój główny sens znajdując we wspólnocie. Wspólnota - jej realizacją, wyrazem, ekspresją - jest zarówno to, co się dzieje na zewnątrz świątyni, jak i to, co ma miejsce w cerkwi.

Ludzie wchodza i wychodza, witają się wylewnie, przed cerkwią rozmawiaja pełnym głosem, ale i w cerkwi zdarzają się głośne rozmowy, rzadko uspokajane przez najbardziej pobożnych. Są wspólnota, całościa właśnie przez to, że duchowny śpiewa i odmawia modły, właśnie dlatego, że tam, w świątyni, odbywa się to, co szczególnie ważne, co jest istota

\footnotetext{
${ }^{7}$ Mówię tu oczywiście o religijności potocznej, a nie klasztornej, której w Grecji w ogóle nie badałam i miałam z nią kontakt dość wyrywkowy.
} 
i podstawą wszystkiego. Polski katolik nie zauważa także charakterystycznej na przykład dla wsi polskiej różnicy między uczestniczeniem różnych kategorii osób - uczestniczeniem ,intensywnym” w religijnym rytuale osób starszych lub szerzej dorosłych i przyprowadzonych przez nich dzieci i równocześnie pewien rodzaj dystansowania się młodzieży, zwłaszcza męskiej, która wystaje czasami licznie przed kościołem, tam prowadząc życie towarzyskie. W greckiej cerkwi życie towarzyskie odbywa się wszędzie - zarówno w świątyni, jak i wokół niej. Ponieważ zbyt głośne rozmowy, śmiechy i przemieszczanie się w cerkwi przeszkadzaja duchownemu (duchownym) celebrującemu obrzęd, część osób wychodzi przed cerkiew, tam kontynuując rozmowy już pełnym głosem i z głośnym śmiechem. Tak samo zachowują się ludzie starsi, jak i młodzi, mężczyźni i kobiety. Wielokrotnie wchodzi się do świątyni i wychodzi z niej, co podczas kilkugodzinnego nabożeństwa może być traktowane jako zrozumiały odpoczynek.

Spostrzeżenia właśnie poczynione odnoszą się zarówno do greckich lokalnych społeczności wiejskich, jak i, trudno zresztą od pierwszych odróżnialnych, małomiasteczkowych. Porównanie greckiej wioski i greckiego małego miasta pod względem obrzędowości religijnej w praktyce życia społecznego wykazuje bardzo głębokie podobieństwo. Strój osób biorących udział w obrzędach na wsi nie różni się zasadniczo od tych, które się nosi w mieście. (Pomijam tu takie duże miasta jak Ateny i Saloniki, gdzie w cerkwi pojawiają się licznie turyści i osoby już spoza społeczności lokalnych). Wyjątkiem jest udział starszych kobiet wiejskich ubranych tradycyjnie na czarno, co spotkać można już bardzo rzadko - raczej na wsi niż w mieście. Dziewczęta wchodzą do cerkwi w strojach bardzo skąpych, obcisłych bluzeczkach, krótkich dopasowanych spodniach. Na obrzędach typu ślub czy chrzest w mieście widać tłumy kobiet i mężczyzn ubranych wieczorowo, bardzo akcentujących elegancję, w uroczystych czy nawet balowych sukniach o różnym stopniu wydekoltowania, przysłoniętych eleganckimi szalami. Głowy zdobią efektowne fryzury, a strojom dodają uroku złota (koniecznie) biżuteria i wyrazisty makijaż. Wszyscy rozmawiaja tak hałaśliwie, że na porządku dziennym sa głośne uwagi duchownego, który wzywa do powagi i ciszy, gdyż jego słów rytualnych w ogóle nie słychać w gwarze i hałasie przyjęcia czy raczej wstępu do przyjęcia. Nie są to przy tym zachowania, które kogokolwiek by oburzały czy dziwiły. Ważne jest, jak można się domyślać, bycie razem, akcentowanie wspólnoty rodzinnej, lokalnej, wioskowej, środowiskowej, ludzi, którzy są sobie bliscy i bliskość tę realizują właśnie przez obrzęd religijny, który ową wspólnotę sankcjonuje, uświęca. Kapłan jest potrzebny, ale nie po to, aby uczestnicy 
rytuału mieli śledzić jego słowa, przeżywać odprawiany obrzęd. Jest potrzebny jako element porządku sakralnego, który porządek świecki namaszcza, uzasadnia, nadaje mu wymiar wieczny, obowiązujący, wspólnotę zakorzeniając tym samym w sacrum.

Grecka religijność w społecznościach lokalnych (bez względu na etniczne różnice w obrębie populacji kraju) nie jest religijnością mistyczna, kontemplacyjna. Zbiorowość, która coś razem przeżywa, nie wyraża w gestach rytualnych znaczeń, które się w tej wspólnocie tworzą. To wspólnota wydaje się mieć jako taka aspekt sakralny, nie słowa wypowiadane podczas religijnego obrzędu, nie przedmioty, gesty, melodie, ale zbiorowość jest celem.

\section{/// Religijne obrzędy i wspólnota lokalna wśród greckich repa- triantów z Polski}

Specyficznego oglądu związku religijności z wspólnotowością w obrębie społeczności lokalnych w Grecji dostarczaja ci Grecy (a ściślej greccy obywatele), których losy wojny domowej, a właściwie kierująca lewicową partyzantką Komunistyczna Partia Grecji i jej mocodawcy w Moskwie, rzuciły na długoletnia, przymusową emigrację do krajów zwanych wówczas krajami demokracji ludowej. Trafili do Polski, Czechosłowacji, NRD, Węgier, Rumunii i Bułgarii, a także do ZSRR (do Taszkientu, Uzbekistan). Stosunek do religii w ogóle i do prawosławia w szczególności, sposób podejścia tej zbiorowości do religijnych obrzędów u osób wychowanych z zasady ateistycznie w duchu komunistycznym (lub co najmniej poza religia) jest godny uwagi, gdyż w jeszcze większym stopniu podkreśla wspólnotowy, a nie refleksyjny, intelektualny czy mistyczny sens uczestnictwa w religijnych obrzędach. Powracając do Grecji, musieli się od nowa (a w wypadku osób młodszych po raz pierwszy) zderzyć z tradycyjną kultura kraju uznanego za rodzinny, ale de facto nieznanego.

W środowisku greckich uchodźców w trakcie pobytu w krajach osiedlenia obowiązkowo panowała atmosfera ateistyczna. Dzieci i młodzi ludzie w ogóle nie mieli szansy poznać treści religijnych, religijnych rytuałów. Jedynie najstarsi, i to nie wszyscy, podtrzymywali w życiu domowym niektóre prawosławne zwyczaje, co było zreszta przedmiotem ataków liderów Komunistycznej Partii Grecji (KPG), która sprawowała władzę nad tysiącami ewakuowanych z obszaru przegranej przez komunistów wojny, celowo trzymanych w ścisłej izolacji od społeczeństwa polskiego, czeskiego, węgierskiego etc. Wychowani przeciw religii, a - co ważniejsze - poza religia - młodzi Grecy nie mieli okazji przyswoić sobie religijnej tradycji 
greckiego prawosławia. Dziś jeden z rozmówców mówi z humorem: „Z Bogiem jest... Boga nie mieliśmy, bo z Bogiem było trochę nie tak (śmiech)". Zauważyć trzeba, że ten człowiek, zdecydowanie w istocie zorientowany ateistycznie, uczestniczy w najważniejszych obrzędach religijnych swojej wsi: „nawet cerkiew tutaj, chodzę tylko na - ja, osobiście, na jakieś święta, jak pogrzeby, jak teraz jest - piętnastego sierpnia, i tak dalej". Rozmówca po powrocie do rodzinnej wsi uczestniczy we wszystkich najważniejszych wydarzeniach religijnego życia, a robi to wyłącznie z motywów społecznych, wspólnotowych. Repatrianci widzą swoją odrębność w zakresie przekonań, światopoglądu i związków z Kościołem prawosławnym. Zdają sobie sprawę ze swojej odmienności w sprawach religii od tych Greków, którzy nigdy nie mieszkali daleko od kraju. Przykładem może być nasza rozmówczyni ze wsi Loutra, religijna raczej na sposób obyczajowy niż głęboki. Nie wszystkie obyczaje cerkiewne dobrze zna, o czym mówi otwarcie, nie wszystkie też akceptuje, jak np. ceremonialne całowanie ikon. Podkreśla, że to obyczaj niehigieniczny, jeśli wszyscy całują to samo miejsce. Stara się jednak zachowywać mniej więcej tak jak inni. Zdaje sobie sprawę, że była wychowana inaczej, bo w Polsce wychowywano dzieci greckie bez religii, komunistycznie, a nawet ateistycznie. Spotykałam się także $\mathrm{z}$ daleko idąca niekompetencja repatriantów w zakresie obyczajów religijnych. Zdarzało się, że moi rozmówcy podczas bytności w cerkwi, zarzucani przez nas pytaniami typu „Co to znaczy?” „Jakie to ma znaczenie?” lub „Co się w tej chwili dzieje?” albo nie umieli odpowiedzieć, albo się spierali między sobą o znaczenie obrazów, treści w nich przedstawianych, sposobów stawiania świeczek i ich zapalania. Wyraźnie ich kompetencja w sprawach obyczajowości religijnej jest niewielka. Ci ateistycznie wychowani repatrianci chętnie uczestniczą w tych obrzędach religijnych, które mają wyraźnie wspólnotowy charakter, co wskazuje na to, że warstwa wierzeń i przekonań religijnych w ścisłym sensie została zniszczona stosunkowo łatwo przez życie w komunistycznej propagandzie i pod presja ciagłego nacisku ideologicznego, natomiast warstwa wspólnotowa religijności związanej ze zbiorowością lokalną pozostała żywa. Sądzę, że stanowi ona element rdzeniowych ${ }^{8}$ wartości kultury greckiej (Smolicz 1984; Smolicz 2000).

Repatrianci potrafia być bardzo krytyczni wobec tych Greków, którzy z kraju nigdy nie byli zmuszeni wyjechać, a krytyka ta dotyczy również

\footnotetext{
${ }^{8}$ Stosuję konsekwentnie w moich publikacjach termin ,wartości rdzeniowe”, a nie, jak proponował po polsku Jerzy Smolicz, „rdzenne”, gdyż sądzę, że doszło po prostu do błędnego tłumaczenia terminu „core values”.
} 
elementów życia religijnego. Jeden z moich rozmówców tak krytykuje Greków wychowanych w Grecji: „Wychodzi się z teatru a teatr jest zaśmiecony, no. A poza tym wchodza, kiedy chca, wychodza, kiedy chca $z$ teatru albo z kina w trakcie. A w kościele to tym bardziej, wchodzi, wychodzi kiedy chce". Rozmówca najwyraźniej wiąże zachowanie w kościele z ogólnym brakiem kultury i manier, przypisując tym, którzy nasiąknęli w ciagu wielu lat w Polsce ogładą i kulturą. O swojej odmienności wobec przeciętnego społeczeństwa greckiego mówią bez wstydu, ale z pewnym zażenowaniem; mają przede wszystkim poczucie, że są inni i są jako inni odbierani. Jednakże znakomita ich większość aktywnie uczestniczy w wioskowych obrzędach religijnych, które są bardziej wioskowe niż religijne w odczuciu zarówno tych, którzy z Grecji nigdy nie musieli wyjechać, jak i tych, którzy poza Grecją i rodzinną wsią spędzili wiele lat. Uczestnictwo w nabożeństwach wypominkowych i następujących po nich wypominkowych przyjęciach koło cerkwi i w domu osoby zmarłej działa na rzecz podtrzymywania kontaktów międzyrodzinnych w obrębie społeczności lokalnej, zarazem będąc manifestacją tejże więzi.

\section{/// Religia i państwo greckie w odczuciach repatriantów}

Specyficzną kategorię stanowią wśród repatriantów najstarsi partyzanci i zdeklarowani komuniści. Mają też zdecydowanie negatywny stosunek do religii, a zwłaszcza do greckiego prawosławia, źródłem religii jest wedlug nich „ciemnota”, „zabobony”, „bajeczki”, „ludzka niewiedza”. Religia wynika w tej konstrukcji myślowej z ignorancji i celowego ogłupiania ludzi przez cerkiew. Na pytanie, czy rozmówca w trudnej sytuacji zwróciłby się do Kościoła, jeden ze starych konsekwentnych komunistów odpowiada: „Kościół - nie zwracam się, wręcz przeciwnie - my mówimy, że Kościół nic dobrego ludziom nie przyniesie”. W kraju, w którym religia państwową jest prawosławie, poglądy takie pozostaja w wyraźnym konflikcie z przeciętnym sposobem myślenia, a także z oficjalną ideologia. W Grecji widoczny jest związek oznak religijności z symbolami państwowymi; na kapliczkach i w cerkwiach pojawia się flaga Grecji, a kolory maja także charakter narodowy, biały i niebieski. Nie ma wyraźnego rozdziału cerkwi od państwa. W takich warunkach rozłączanie interesów narodu od greckiej cerkwi prawosławnej może komplikować sytuację osoby, która znacznie odbiega od ogólnego stylu zachowania i myślenia. Nie znaczy to, aby Grecy w przewadze okazywali wysoka pobożność czy pogłębioną wiarę, ale cerkiew, obrzędy religijne, uroczystości państwowe zrosły się i od stuleci jednym towarzyszą drugie. Nie ma watpliwości, że wiele setek lat 
trwająca podległość muzułmańskiemu imperium otomańskiemu sprawiła, iż chrześcijaństwo stało się symbolem narodowej odmienności, a ośrodki kultu religijnego miejscem organizowania oporu wobec obcej władzy. Dziś z religijnym aspektem prawa obowiązującego w Grecji stykają się repatrianci. Bez ślubu w cerkwi do niedawna nie dało się zalegalizować małżeństwa. O swoim niezawartym w cerkwi małżeństwie opowiada 81-letni komunista: „Trzeba powiedzieć, że wszyscy emigranci polityczni są jednego zdania - wszystkie religie, jak to powiedzieć - odrzucili dawno temu. 50 lat my nie mieliśmy. A w dokumentach - rozumiecie, jeśli w Grecji spytają: czy brałeś ślub? Ja mówię: tak. To pokaż dokumenty. A dokumenty kto tu wydaje - kler! A u nas - ja z żoną nigdy nie byłem ani w cerkwi, ani nigdzie. My się porozumieliśmy, żyliśmy, mamy troje dzieci - niczego więcej nie potrzeba. Kiedy wróciliśmy do Grecji, tu mówią - tu potrzeba mieć dokument. Jeśli nie przyniesiecie dokumentu, że jesteście mężem i żoną - to was nie przyjmiemy. I musimy iść do popa".

Kłopoty z legalizacją małżeństw mieli także ci repatrianci, z przekonania prawosławni, nawet ci, którzy zawarli małżeństwo już w Polsce, $\mathrm{i}$ to w cerkwi. Moi rozmówcy, którzy przyjechali do Grecji wyjątkowo wcześnie, w 1965 roku, krótko po ślubie cywilnym i zawartym w cerkwi, tyle że w Polsce na Dolnym Śląsku, w Grecji musieli ponownie brać ślub w cerkwi, aby ich małżeństwo było legalne. Żartują że brali ślub trzykrotnie: w urzędzie stanu cywilnego, w cerkwi w Polsce i w cerkwi w Grecji i tak związani na pewno się nigdy nie rozejda.

Znalazły się też wśród repatriantów osoby, które po powrocie do Grecji z gorliwością (a nawet nadgorliwościa) wracają do praktyk religijnych. Zdarzają się także nawrócenia i, nawet w starszym wieku, gwałtowne zmiany postaw. Jedna $\mathrm{z}$ najstarszych kobiet $\mathrm{z}$ badanej wsi w górach Pajkos mówi o tym, że po babci odziedziczyła imię i zaangażowanie religijne. „W Czechosłowacji byłam w cerkwi, to dla mnie interesujące. Bożenka i Jarka (jej koleżanki Czeszki - E.N.) były, to jest katolicki kościól, ale chodziłam. Interesujace to dla mnie było. W Rosji nie, bo tam zawsze propaganda antyreligijna była. U mnie w duszy cały czas coś było. Jakbym wierzyła w Boga. Kiedy tu przyszliśmy, pracy tak dużo, nie było czasu chodzić do cerkwi. Teraz czasu dużo, emerytura, staruszki, jak należy...”. Zakończenie tej wypowiedzi wskazuje na pewien rodzaj dystansu do własnej religijności i zaangażowania w sprawy cerkwi. Kobieta ta w lokalnej cerkwi zajmuje się utrzymywaniem porządku i sprzedażą świeczek, ale i pouczaniem osób, które się zachowują niestosownie. Jest zdecydowanie surowa i autorytarna. Inne, młodsze kobiety, również repatriantki boją się 
jej ocen i pouczeń świadczących o ich nieznajomości zasad zachowania się w kościele. $\mathrm{Na}$ przykład jedna z młodszych repatriantek przyszła do cerkwi i chciała kupić dziesięć świeczek, lecz okazało się, że zabrakło jej pieniędzy, zaczęła się nam zwierzać z przerażeniem, że teraz zaczną się we wsi plotki o niej, gdyż starsza kobieta na pewno wszystkim rozpowie o jej niestosownym zachowaniu. Zarazem trzeba podkreślić, że z pewną obawa o niewłaściwość zachowania repatrianci na ogół uczestnicza, przynajmniej chwilowo, w obrzędach cerkiewnych, czasem wchodząc do świątyni jedynie na chwilę, jakby dla zaznaczenia swojej tam bytności.

Symptomatyczne jest także, że historię cerkwi stojącej we wsi, w której prowadziłam długą obserwację terenowa, opowiadaja jednak także nastawieni lewicowo, nawet repatrianci komuniści:

„W pierwszej wojnie światowej tutaj w pobliżu przechodziła granica i ładunek $\mathrm{z}$ armaty uderzył w cerkiew. I dziurę do dziś widać. Zamurowali ją, kratę zrobili, ale widać. Potem była druga wojna i wojna domowa, i cerkwi nie ruszali. Przecież chrześcijanie... Nie było muzułmanów, Turcy nie przyszli. Czterysta lat. Grecja była okupowana przez Turcję... Do naszej wsi nie przyszli. Czyli jakiś cud, bo chcieli kościół spalić, ale (...) Starsi mówili, rzucili tam ogień i nie zapaliło się. Ja nie mogę być świadkiem, ja wtedy byłam mała. Dorośli mówili. Mogę mówić jako świadek, jeśli sama widzę i słyszę. A co inni mówią - nie wierzę. Mówią, że Matka Boska uchroniła cerkiew, my chcemy, żeby tak było i wierzymy tak". Głębokość wiary religijnej jest w gruncie rzeczy chwiejna, ale poczucie, że cerkiew jest miejscem wyjątkowym, nie jest podważalne. Zauważalny jest znowu najgłębszy i najistotniejszy podział w oczach badanych na osoby o zapleczu chrześcijańskim i muzułmanów. Wydaje się, że w ich oczach podział na greckich ateistów - komunistów, i greckich prawosławnych nie jest już tak istotny. Czas leczy rany na ciele społeczeństwa greckiego, zaciera podziały na tych, którzy byli związani z partyzantką komunistyczną i ich przeciwników i łagodzi konflikty, choć nie można powiedzieć, że podskórnie one nie trwają. Nawet więc u tych, którzy się od nowa zaangażowali w sprawy religii i cerkwi pozostal pewien rodzaj dystansu i patrzenia z zewnątrz; różni ich to od reszty wsi - tych, którzy do cerkwi chodzą nawykowo i bezrefleksyjnie.

Społeczeństwo greckie - jeśli sobie pozwolić na daleko idące uogólnienie - zbudowane jest na więzi rodzinnej, wspólnotowej (wioskowej, wyspiarskiej), czyli lokalnej i narodowej; tu zajmowałam się jedynie tą druga, którą w swoich ciekawych rozważaniach pomijał Michael Herzfeld (2007). Na każdym poziomie wspólnoty pewną rolę odgrywa prawosławie, 
przy czym jest ono konsekwentnie zewnętrzną warstwa sakralizującą raczej niż esencjonalną istotą rytuałów i sposobów myślenia. Przejawia się to $\mathrm{w}$ charakterystycznym sposobie uczestniczenia w praktykach religijnych, który określiłam wcześniej jako wspólnotowy, a nie indywidualistyczny.

Bibliografia:

/// Durkheim, Emil. 1963. Sociologie etphilosophie. Paris: Presses Universitaires de France.

/// Durkheim, Emil. 1990. Elementarne formy życia religijnego. System totemiczny w Australii. Przeł. A. Zadrożyńska. Warszawa.

/// Herzfeld, Michael. 2007. Zaìytość kulturowa. Poetyka spoteczna w państwie narodonym, Przeł. M. Buchowski. Kraków: Wydawnictwo UJ.

/// Nowicka, Ewa. 2008a. Hermes Odyseusz i greckie powroty do ojcayzny. Kraków: Zakład Wydawniczy Nomos.

/// Nowicka, Ewa. 2008b. Identity of Greek repatriates from Poland. Return home or new migration? W: E. Nowicka, H. Firouzbakhch (red.). Homecoming. An Anthropology of Return Migrations. Kraków: Zakład Wydawniczy Nomos, s. $59-78$.

/// Smolicz Jerzy. 1984. Wartości rdz̨enne. W: Kultura i społeczeństwo.

/// Smolicz, Jerzy. 2000. Wspótkultury Australii. Warszawa: Oficyna Naukowa /// Szacki, Jerzy. 2002: Historia myśli socjologicznej. Wydanie nowe. Warszawa: Wydawnictwo Naukowe PWN.

/// Wace, Alan J.B. i Thompson Maurice. 1914. The nomads of the Balkans. An account of life and customs among the Vlachs of northern Pindus. London: Methuen \& Co. ltd.. 


\section{/// Abstrakt}

Artykuł ukazuje pewien aspekt greckiej kultury, która - nie stosując żadnych ocen - przedstawia w swoich intensywnych przejawach lokalności wzór dla antropologa wyjątkowo interesujący. Wnika on w tajniki i szczegóły ściśle lokalnej i terytorialnej (wioskowej lub wyspowej) więzi społecznej na obszarze Grecji, szczególnie ważnej dla zrozumienia społeczeństwa greckiego. Emil Durkheim znalazłby w tych analizach doskonała ilustrację swojej tezy, iż religia jest tam, gdzie społeczeństwo uprawia kult samego siebie. Artykuł zawiera refleksję antropologa społecznego nad obrzędowością religijną we współczesnej Grecji zarówno w środowisku wiejskim, jak i miejskim na terenie Macedonii Egejskiej. Materiał empiryczny pochodzi z kilkuletnich badań terenowych przeprowadzonych w latach 2005-2010. Przedmiotem analizy jest stosunek do religii, uczestnictwo w religijnych obrzędach między innymi pewnej specyficznej kategorii Greków, migrantów powrotnych - tych, którzy powrócili (czasem w drugim pokoleniu) do rodzinnego kraju po długim okresie politycznej emigracji w Polsce i innych krajach bloku wschodniego. Wśród badanych określanych zbiorczo jako Grecy, zwłaszcza na północy kraju, to etniczne/narodowe mniejszości. Analizie zostały poddane religijne obrzędy w wioskach Macedonii Egejskiej (Loutra) i Epiru (Samarina), a także zachowania uczestników takich obrzędów jak chrzty czy nabożeństwa wypominkowe w różnych miejscowościach. Wnioskiem jest stwierdzenie, że to poczucie jedności, solidarności i więzi społeczne. Wspólna zabawa, przebywanie razem, odbywanie wspólnie wielu czynności rytualnych, które wprawdzie wiążą się ze świętem religijnym, ale daleko sięgaja w życie świeckie, pełnia funkcje integracyjne. Uzasadnia to oparcie się na socjocentrycznej Durkheimowskiej koncepcji religii.

Słowa kluczowe:

Grecy, lokalność, religia, obrzędy, Durkheim 


\section{/// Abstract}

The article shows certain aspect of Greek culture, which presents in its intensive manifestations a pattern particularly interesting for an anthropologist. It explores secrets and details of local and territorial (village or island) vital for the understanding of the Greek society social bonds on the territory of Greece. Emil Durkheim would have found in the analysis a perfect illustration of his statement that religion is there, where the society worships itself. The article contains a reflection of a social anthropologist on religious rituality in contemporary Greece both in the rural and municipal environment on the territory of Aegean Macedonia. Empirical material was collected during several years of fieldwork in the years 2005-2010. The subject of the analysis is an attitude towards religion, participation in the religious rituals of certain particular category of Greeks, return migrants who have come back (sometimes in the second generation) to the home country after a long period of political migration in Poland and other communist countries. Among the researchees described as Greek, especially in the northern Greece, they are ethnic/national minorities. Religious rituals in the villages of Aegean Macedonia (Loutra) and Epir (Samarina) have been analyzed as well as the behavior of the participants of such rituals like baptisms, post-funeral ceremonies in different villages. The conclusion is the statement about unity, solidarity and social bonds. A common celebration, being together, performing of ritual activities, which are part of religious celebration, go further into mundane life, fulfill integrative functions. This justificates the usage of Durkheim's sociocentric concept of religion.

Keywords:

Greek, locality, religion, rituals, Durkheim 